\title{
Fairtrade Wine Price Dispersion in the United Kingdom*
}

\author{
Britta Niklas $^{\text {a }}$, Karl Storchmann ${ }^{b}$ and Nick Vink ${ }^{c}$
}

\begin{abstract}
This paper analyzes wine price dispersion in the United Kingdom. In particular, we are interested in examining whether Fairtrade wines are different from non-Fairtrade wines. Because Fairtrade wines serve an additional social purpose, one may think that consumers search less aggressively for the outlet with the lowest price, thus allowing for a larger price dispersion than for regular wines. We draw on data for about seven thousand wines from South Africa, Fairtrade and non-Fairtrade, sold in the United Kingdom between 2007 and 2012. In a first step, we run a hedonic regression model explaining the wine prices using Ordinary Least Squares (OLS) and Two-Stage Least Squares (2SLS) Instrumental Variable (IV) approaches. In the next step, we regress the squared residuals from the first step on a Fairtrade 0-1 dummy-variable. When using the squared residuals from the OLS model, we find that Fairtrade is a negative determinant of price dispersion. Therefore, Fairtrade wines exhibit a significant lower price dispersion than the comparison group. When using the squared residuals from the IV model, we find mixed results and suspect the presence of a substantial bias due to weak instruments. Finally, in order to avoid IV pitfalls, we ran Fairtrade and NonFairtrade wines in separate equations. We find support for the OLS results, i.e., Fairtrade wines appear to exhibit lower price dispersion than their non-Fairtrade counterparts. Whether this is due to consumer search is a priori unclear. (JEL Classifications: L31, L81, Q11)
\end{abstract}

Keywords: Fairtrade, price dispersion, wine.

\section{Introduction}

Fairtrade is an organized social movement that promotes social, economic, and environmental standards in areas related to the production and trading of "Fairtrade"

\footnotetext{
* We are grateful to an anonymous reviewer as well as to participants at the American Association of Wine Economists (AAWE) conferences in Walla Walla, Washington, in 2014, and in Mendoza, Argentina, in 2015.

${ }^{a}$ Institute of Development Research and Development Policy, Ruhr-University Bochum, Universitätsstr.105, 44789 Bochum, Germany; e-mail: britta.niklas@rub.de (corresponding author).

${ }^{\mathrm{b}}$ Economics Department, New York University, 19 W. 4th St., New York, NY 10012; e-mail: karl.storchmann@, nyu.edu.

${ }^{\mathrm{c}}$ Department of Agricultural Economics, Stellenbosch University, Private Bag X1, Matieland, 7602, South Africa; e-mail: nv@sun.ac.za.
} 
labeled goods. The Fairtrade label was launched in $1988^{1}$ by the Dutch development agency Solidaridad, which started to sell Fairtrade coffee from Mexico and Nicaragua under the Max Havelaar Fair Trade label. The aim was to help economically disadvantaged and marginalized producers and workers in developing countries get fair access to markets under better trading conditions across the entire supply chain, inter alia through the establishment of long-term trading relationships.

The initiative was replicated in the United States, Canada, and several countries throughout Europe and Asia, where coffee, tea, cocoa products, bananas, and so forth were sold in "World Shops" or "Alternative Trading Associations" (ATOs) being represented by the Fair Trade Federation (FTF) and the World Fair Trade Organization (WFTO). To unite these different labeling initiatives and to establish worldwide standards and certification, Fairtrade Labeling Organizations (FLO) International was established in Bonn, Germany, in 1997. It launched a new international Fairtrade Certification Mark in 2002 to enhance the visibility of Fairtrade. In 2004, the FLO split into FLO International, with responsibility for setting and maintaining Fairtrade Standards (agreed upon through a process of research and consultations) as well as for offering business support to producers, and into FLO-CERT (2012), with responsibility for inspections and certification of producer organizations.

The standards set by FLO International serve as minimum criteria to ensure that conditions for production and trade are socially, economically, and environmentally responsible. The means to achieve these goals include i) a price floor; ii) Fairtrade premiums; iii) stability and access to credit; iv) establishment of working-condition standard; ${ }^{2}$ v) encouragement of institutional structures, such as cooperatives; and vi) establishment of environmental standards (Dragusanu, Giovannucci, and Nunn, 2014).

It is not a priori clear that the ambitious Fairtrade goals have been achieved. Based on randomized controlled trials, Granville and Telford (2013) analyze the impact of Fairtrade on landless workers in the South African wine industry. Although they find that Fairtrade workers are not more likely to report higher incomes or better health and education outcomes than non-Fairtrade workers, they do report a higher standard of living and a higher degree of motivation to participate in joint body activities. Granville and Telford conclude, "[T]he data suggests that Fairtrade appears to be clearly achieving at least two of its objectives" (326).

The first wine farm to achieve Fairtrade certification globally was South Africa's Thandi Wines in 2003 (Fairtrade Label South Africa, 2012), and South African wines are still dominant in the Fairtrade wine sector. In 2012, the last year of our database, there were 46 certified wine producers, coming from South Africa (17), Chile (13), Argentina (14), Brazil (1), and Lebanon (1) (FLO-CERT, 2012).

\footnotetext{
${ }^{1}$ This information originated on the website of the Fairtrade Foundation (2012).

2 “"F]reedom of association, safe working conditions, and wages at least equal to the legal minimum or regional averages. Some forms of child labor are prohibited" (Dragusanu, Giovannucci, and Nunn, 2014, 221).
} 
The United Kingdom is the world's largest market for Fairtrade products in general, and for wine in particular. Of the worldwide sales of 22.2 billion liters in 2016, almost half (i.e., 10.9 billion liters) was sold in the United Kingdom (Fairtrade Foundation UK, 2017).

In this paper, we analyze the market for South African Fairtrade certified wine in the United Kingdom and focus on its price dispersion. A large and growing body of information-theory literature has analyzed and found considerable price dispersion even for standardized products (for a survey, see Jaeger and Storchmann, 2011). Various empirical studies have explicitly examined the association between consumer search and price dispersion for homogenous goods (e.g., Jaeger and Storchmann, 2011; Pratt, Wise, and Zeckhauser, 1979; Sorensen, 2000). In general, when search costs are high, consumers may be less inclined to look for the retail outlets with the lowest prices, allowing for higher price dispersion. We argue that the same relation may hold for goods with socially desirable and charitable connotations, such a Fairtrade products. Compared to when they buy regular wine, consumers may derive additional utility in the form of prestige, respect, friendship, social acclaim (Becker, 1974; Olson, 1965), or some "warm glow" (Andreoni, 1990). Therefore, the price may not be as important as otherwise, resulting in a somewhat lower search intensity for Fairtrade wine. This circumstance, in turn, may give rise to a higher price dispersion for Fairtrade wine.

We examine this question empirically for South African Fairtrade certified wine sold in the United Kingdom between 2007 and 2012 and find no support for the above-mentioned hypothesis.

The remainder of this article is organized as follows: Section II presents and interprets the data; In Section III we describe our empirical strategy and report the result. Section IV concludes.

\section{Data}

Our analysis draws on retail price postings of South African wine by wine stores in the United Kingdom between 2007 and 2012; we collected this information from the website www.wine-searcher.com. Although our total sample comprises 7,315 wine postings, we could not utilize all of them, as some were incomplete. For instance, for all nonvintage wines, we could not calculate the age. Critical scores, as provided by winesearcher.com, ${ }^{3}$ were available only for 1,089 wines in our sample. Table 1 reports some descriptive statistics for the entire sample as well as for the Fairtrade sub-group.

Fairtrade wines are, on average, less expensive than wines of the comparison group. Compared to the mean wine price of $€ 14.11$ in the sample, average

\footnotetext{
${ }^{3}$ Wine-searcher.com provides an aggregated score composed of ratings of various wine critics, notably Robert Parker and Wine Spectator. The score is out of 100 points (Wine Searcher, 2017).
} 
Table 1

Descriptive Statistics

\begin{tabular}{|c|c|c|c|c|c|c|}
\hline & & Obs & mean & Std Dev & Min & $\operatorname{Max}$ \\
\hline \multirow[t]{2}{*}{ Price } & all & 7,309 & 14.11 & 17.65 & 1.67 & 464.20 \\
\hline & of which FT & 484 & 11.42 & 10.43 & 4.05 & 185.00 \\
\hline \multirow[t]{2}{*}{ Age } & all & 6,945 & 2.68 & 1.89 & 0 & 36 \\
\hline & of which FT & 469 & 2.39 & 1.46 & 0 & 7 \\
\hline \multirow[t]{2}{*}{ Fairtrade } & all & 7,315 & 0.066 & 0.25 & 0 & 1 \\
\hline & of which FT & 484 & 1 & 0 & 1 & 1 \\
\hline \multirow[t]{2}{*}{ Critical Score } & all & 1,089 & 87.72 & 2.65 & 75 & 98 \\
\hline & of which FT & 42 & 88.02 & 0.78 & 86 & 91 \\
\hline \multirow[t]{2}{*}{ Year of Sale } & all & 7,298 & 2009.32 & 1.46 & 2007 & 2012 \\
\hline & of which FT & 484 & 2010.45 & 1.36 & 2007 & 2012 \\
\hline \multirow[t]{2}{*}{ Sauvignon Blanc } & all & 7,315 & 0.331 & 0.47 & 0 & 1 \\
\hline & of which FT & 484 & 0.242 & 0.43 & 0 & 1 \\
\hline \multirow[t]{2}{*}{ Pinotage } & all & 7,315 & 0.162 & 0.37 & 0 & 1 \\
\hline & of which FT & 484 & 0.056 & 0.23 & 0 & 1 \\
\hline \multirow[t]{2}{*}{ Syrah } & all & 7,315 & 0.130 & 0.34 & 0 & 1 \\
\hline & of which FT & 484 & 0.188 & 0.39 & 0 & 1 \\
\hline \multirow[t]{2}{*}{ Chenin Blanc } & all & 7,315 & 0.099 & 0.30 & 0 & 1 \\
\hline & of which FT & 484 & 0.180 & 0.38 & 0 & 1 \\
\hline \multirow[t]{2}{*}{ Merlot } & all & 7,315 & 0.093 & 0.29 & 0 & 1 \\
\hline & of which FT & 484 & 0.110 & 0.31 & 0 & 1 \\
\hline \multirow[t]{2}{*}{ Chardonnay } & all & 7,315 & 0.093 & 0.29 & 0 & 1 \\
\hline & of which FT & 484 & 0.046 & 0.21 & 0 & 1 \\
\hline \multirow[t]{2}{*}{ Cabernet Sauv } & all & 7,315 & 0.082 & 0.27 & 0 & 1 \\
\hline & of which FT & 484 & 0.182 & 0.39 & 0 & 1 \\
\hline \multirow[t]{2}{*}{ Pinot Noir } & all & 7,315 & 0.031 & 0.17 & 0 & 1 \\
\hline & of which FT & 484 & 0.002 & 0.05 & 0 & 1 \\
\hline \multirow[t]{2}{*}{ Viognier } & all & 7,315 & 0.010 & 0.10 & 0 & 1 \\
\hline & of which FT & 484 & 0.004 & 0.06 & 0 & 1 \\
\hline \multirow[t]{2}{*}{ Semillon } & all & 7,315 & 0.001 & 0.03 & 0 & 1 \\
\hline & of which FT & 484 & 0.002 & 0.05 & 0 & 1 \\
\hline \multirow[t]{2}{*}{ Cabernet Franc } & all & 7,315 & 0.001 & 0.03 & 0 & 1 \\
\hline & of which FT & 0 & 0.000 & 0.00 & 0 & 0 \\
\hline \multirow[t]{2}{*}{ Muscat } & all & 7,315 & 0.001 & 0.02 & 0 & 1 \\
\hline & of which FT & 484 & 0.006 & 0.08 & 0 & 1 \\
\hline \multirow[t]{2}{*}{ Malbec } & all & 7,315 & 0.0003 & 0.02 & 0 & 1 \\
\hline & of which FT & 484 & 0.0000 & 0.00 & 0 & 0 \\
\hline \multirow[t]{2}{*}{ Grenache } & all & 7,315 & 0.0003 & 0.02 & 0 & 1 \\
\hline & of which FT & 484 & 0.0000 & 0.00 & 0 & 0 \\
\hline
\end{tabular}

Fairtrade wine prices are almost 20 percent lower (€11.42). In addition, Fairtrade wine prices exhibit a substantially smaller range and standard deviation than other wines. However, that does not necessarily mean that Fairtrade exhibit a lower price dispersion.

Fairtrade wines are notably different from other wines not only with respect to their price. Although they receive similar critical quality scores, the score range is much smaller. Non-Fairtrade wines display a range of 21 points (between 77 and 
98 points), but Fairtrade wines only show a 5-point range (between 86 and 91 points), suggesting that their quality is much more uniform.

Furthermore, Fairtrade wines in our sample show a grape-variety profile that is distinctly different from that of the whole sample. The grape-variety dummy variables in Table 1 are sorted by their relative importance for the entire sample. Because their values equal either zero or one, the mean values reflect the percentage of wines that contain the corresponding variety or characteristic. For instance, a mean sample value of 0.331 for Sauvignon Blanc reflects that 33.1 percent of the wines in the entire sample contain this grape variety.

Therefore, although all South African wines in our sample are predominantly produced with Sauvignon Blanc (33.1\%), Pinotage (16.2\%), Syrah (13.0\%), and Chenin Blanc (9.9\%), Fairtrade predominantly relies on Sauvignon Blanc (24.2\%), Syrah (18.8\%), Cabernet Sauvignon (18.2\%), and Chenin Blanc (18.0\%). Overall, Fairtrade wines are slightly more likely to be red wines $(52.1 \%$ of all Fairtrade wines) than is the case in the entire sample $(46.8 \%)$.

\section{Methods and Results}

\section{A. Combined Equations}

\section{(1) Hedonic Model}

In general, we follow a two-step approach. First, we run a hedonic model to explain the prices of all wines in our sample. Second, we square the residuals and regress them on the Fairtrade dummy variable. Our reasoning is as follows: If, e.g., the Fairtrade variable were a significant explanatory variable for the squared residuals, Fairtrade wines would display a higher degree of price dispersion than non-Fairtrade wines. Note that we do not examine the price dispersion of identical wines but of similar wines, after controlling for various characteristics.

Our first hedonic equation follows the standard model:

$$
\begin{aligned}
\ln \left(P_{i}\right)= & b_{0}+b_{1} F T_{i t}+b_{2} \text { age }_{i t}+b_{3}(\text { age } * F T)_{i t}+b_{4} \text { trend }_{t} \\
& +b_{5}(\text { trend } * F T)_{i t}+\sum_{k} a_{k} D_{k i t}+e_{i t},
\end{aligned}
$$

where $F T$ denotes a Fairtrade dummy variable, age is the age of the wine at the time of posting, and trend is an annual trend variable. $D_{k i t}$ is a set of assorted dummy variables. We add vintage dummies to capture annual quality variations, producer dummies for time-invariant firm factors, and grape-variety dummies to control for varietal-related price effects. $e_{i t}$ is a random error term.

Column (1) of Table 2 reports the result of a simple Ordinary Least Squares (OLS) regression where the dependent variable is the natural logarithm of the price. The 
Table 2

Determinants of Wine Prices

OLS and 2SLS Instrumental Variable Approach

Dependent Variable In(Price)

\begin{tabular}{|c|c|c|c|c|}
\hline & $\begin{array}{l}O L S \\
\text { (1) }\end{array}$ & $\begin{array}{l}O L S \\
(2)\end{array}$ & $\begin{array}{l}I V^{a} \\
(3)\end{array}$ & $\begin{array}{l}I V^{a} \\
(4)\end{array}$ \\
\hline Fairtrade & $\begin{array}{c}-0.274 * * * \\
\quad(-3.17)\end{array}$ & $\begin{array}{c}-0.537 * * * \\
(-3.15)\end{array}$ & $\begin{array}{c}-0.667^{* * *} \\
(-5.12)\end{array}$ & $\begin{array}{l}-0.498 \\
\quad(-0.12)\end{array}$ \\
\hline Age & $\begin{array}{c}0.033 * * * \\
(9.11)\end{array}$ & $\begin{array}{l}0.195 \\
(0.79)\end{array}$ & $\begin{array}{c}0.032^{* * *} \\
(9.15)\end{array}$ & $\begin{array}{l}0.215 \\
\quad(0.81)\end{array}$ \\
\hline Age*Fairtrade & $\begin{array}{l}-0.026^{*} \\
(-2.11)\end{array}$ & $\begin{array}{l}-0.012 \\
\quad(-0.26)\end{array}$ & $\begin{array}{l}-0.010 \\
\quad(-0.64)\end{array}$ & $\begin{array}{l}-0.040 \\
(-0.09)\end{array}$ \\
\hline Trend & $\begin{array}{c}0.018^{* * *} \\
(3.41)\end{array}$ & $\begin{array}{l}-0.127 \\
(-0.51)\end{array}$ & $\begin{array}{r}0.014 * * \\
(2.54)\end{array}$ & $\begin{array}{r}-0.152 \\
(-0.51)\end{array}$ \\
\hline Trend*Fairtrade & $\begin{array}{c}0.046 * * * \\
(3.56)\end{array}$ & $\begin{array}{c}0.102 * * * \\
(3.34)\end{array}$ & $\begin{array}{c}0.100 * * * \\
(4.09)\end{array}$ & $\begin{array}{l}0.126 \\
\quad(0.23)\end{array}$ \\
\hline Quality Score & & $\begin{array}{c}0.032 * * * \\
\quad(4.18)\end{array}$ & & $\begin{array}{r}0.037^{* *} \\
(3.36)\end{array}$ \\
\hline Obs & 6,939 & 1,088 & 6,679 & 1,005 \\
\hline R2 & 0.437 & 0.551 & 0.351 & 0.620 \\
\hline RMSE & 0.385 & 0.413 & 0.370 & 0.474 \\
\hline Coefficient of Variation (CV) & $15.75 \%$ & $15.70 \%$ & $15.14 \%$ & $18.05 \%$ \\
\hline \multicolumn{3}{|c|}{ Montiel-Pflueger robust weak instrument test } & 9.450 & 2.582 \\
\hline \multicolumn{3}{|c|}{ Worst case bias $\tau=10 \%$} & 15.684 & 16.760 \\
\hline \multicolumn{5}{|l|}{ First Stage (exogenous variables) } \\
\hline \multicolumn{3}{|l|}{ first year of bottling } & $-0.000^{+}$ & 0.001 \\
\hline & $-0.002 * *$ & -0.000 \\
\hline \multirow{2}{*}{\multicolumn{3}{|c|}{ share of red production }} & $-0.013^{*}$ & -0.013 \\
\hline & \multicolumn{2}{|c|}{ First Stage R2 } & 0.958 & 0.922 \\
\hline
\end{tabular}

a 2 SLS Instrumental Variable Regression; robust t-statistics in parentheses; significance levels $1 \%\left({ }^{* * *}\right), 2 \%(* *), 5 \%(*), 10 \%\left({ }^{+}\right)$; all equations include fixed effects for producer, grape variety, and vintage.

results suggest a substantial negative price effect for Fairtrade wine of approximately -27 percent. In contrast to the overall sample, Fairtrade wine does not benefit from aging (i.e., the age Fairtrade interaction almost completely offsets the positive general age effect). However, Fairtrade wines exhibit above-average trend effects (i.e., the trend $^{*}$ Fairtrade interaction suggests that Fairtrade wines have experienced annual price increases of approximately $4.6 \%$, in addition to the $1.8 \%$ for the entire sample).

Although we think we captured the wines' quality by controlling for producer, vintage, and grape variety, in column (2) of Table 2, we also report an alternative regression that includes critical scores. However, adding this variable comes at a high cost (i.e., our sample size now drops by almost $85 \%$, from 6,939 to 1,088 ). In general, the results are similar to those reported in column (1), only all Fairtrade effects are more pronounced. 
However, and as already seen in the data discussion of Section II, there is considerable doubt regarding whether being Fairtrade is a random treatment. Given the fact that Fairtrade wines are distinctly different from non-Fairtrade wines in many characteristics, we assume that the Fairtrade treatment is endogenous. We, therefore, instrument being Fairtrade. Our exogenous instruments are regional dummies of the winery location in South Africa as well as the winery's age (i.e., year of first bottling), its size (tons of production) and the share of red wines produced.

Column (3) of Table 2 reports the 2SLS results. The regression suggests an even larger Fairtrade price discount of 67 percent compared to non-Fairtrade wine. Although the age*Fairtrade interaction becomes insignificant in the IV variant, the trend*Fairtrade interaction is now much stronger than in the OLS version. As in the OLS version, we also add the critical score variable to the IV model. As shown in column (4) of Table 2, the number of observations falls to 1,005; except for the critical score variable, all other variables become insignificant.

However, Montiel-Pflueger's robust weak instrument test suggests a substantial bias for both IV regressions. Given the very low test score, we cannot reject the null hypothesis that the bias in our estimator is greater than $10 \%$ of the worst-case bias.

To recap, OLS and IV regressions suggest that i) Fairtrade wine prices are significantly lower than those of their non-Fairtrade counterparts and ii) Fairtrade wines are on a steeper trend line and enjoy larger annual price increases than non-Fairtrade wines. The addition of critical scores to the regressions results in the loss of 85 percent in the number of our observations and seems to add little benefit.

\section{(2) Empirical Analysis of Squared Residuals}

Our next step is the analysis of the residuals from the last Section. We square the residuals to only work with positive values and then run the following simple linear regression:

$$
\hat{\varepsilon}_{i t}^{2}=a_{0}+a_{1} F T_{i t}+u_{i t},
$$

where $\hat{\varepsilon}^{2}$ is the squared residuals and $u_{i t}$ is a random error term.

Table 3 reports the results. Note that the column numbers in the table correspond to the numbers in Table 2. That is, in column (1) we regress the squared residual of the first OLS regression (column (1) in Table 2). We employ two different methods, OLS and quantile regressions, to examine varying patterns over the price quantiles.

When regressing the squared residuals obtained from the OLS regression, we find a significantly negative effect of Fairtrade, suggesting that the price dispersion of similar wines is smaller for Fairtrade wines than for non-Fairtrade wines. That 
Table 3

Fairtrade as Determinant of Squared Residuals $\hat{\boldsymbol{\varepsilon}}^{2}$ from Table 2

Coefficients $\mathbf{b}_{1}$ of Equation $\hat{\varepsilon}^{2}=b_{0}+b_{1}$ Fairtrade

OLS and 2SLS Instrumental Variable Approach

\begin{tabular}{|c|c|c|c|c|}
\hline & $\begin{array}{c}\hat{\varepsilon}^{2} \text { from } O L S \\
\text { regression } \\
(1)\end{array}$ & $\begin{array}{c}\hat{\varepsilon}^{2} \text { from } O L S \\
\text { regression with quality } \\
\text { scores } \\
\text { (2) }\end{array}$ & $\begin{array}{l}\hat{\varepsilon}^{2} \text { from IV } \\
\text { regression } \\
\text { (3) }\end{array}$ & $\begin{array}{c}\hat{\varepsilon}^{2} \text { from IV regression } \\
\text { with quality scores } \\
\text { (4) }\end{array}$ \\
\hline OLS & $\begin{array}{c}-0.053 * * * \\
(-2.74)\end{array}$ & $\begin{array}{c}-0.095 * * * \\
(-3.59)\end{array}$ & $\begin{array}{c}0.174 * * * \\
(5.07)\end{array}$ & $\begin{array}{c}-0.114^{* * *} \\
(-3.80)\end{array}$ \\
\hline $\begin{array}{l}\text { Quantile Regressions } \\
\tau=0.10\end{array}$ & $\begin{array}{l}-0.000 \\
(-1.06)\end{array}$ & $\begin{array}{c}-0.001 \\
(-1.03)\end{array}$ & $\begin{array}{c}0.003 * * * \\
(9.95)\end{array}$ & $\begin{array}{c}-0.000 \\
(-0.38)\end{array}$ \\
\hline$\tau=0.25$ & $\begin{array}{r}-0.001^{*} \\
(-1.41)\end{array}$ & $\begin{array}{l}-0.003 \\
(-0.91)\end{array}$ & $\begin{array}{c}0.021 * * * \\
(17.12)\end{array}$ & $\begin{array}{l}-0.004 \\
(-0.96)\end{array}$ \\
\hline$\tau=0.50$ & $\begin{array}{c}-0.008 * * * \\
(-2.64)\end{array}$ & $\begin{array}{r}-0.020^{+} \\
(-1.66)\end{array}$ & $\begin{array}{c}0.091 * * * \\
(22.87)\end{array}$ & $\begin{array}{c}-0.016 \\
(-1.21)\end{array}$ \\
\hline$\tau=0.75$ & $\begin{array}{c}-0.035^{* * *} \\
(-3.21)\end{array}$ & $\begin{array}{c}-0.062 \\
(-1.63)\end{array}$ & $\begin{array}{c}0.309 * * * \\
(24.16)\end{array}$ & $\begin{array}{r}-0.074 * * \\
(-2.49)\end{array}$ \\
\hline$\tau=0.90$ & $\begin{array}{c}-0.088 * * * \\
(-2.75)\end{array}$ & $\begin{array}{r}-0.038 \\
(-0.24)\end{array}$ & $\begin{array}{c}0.515 * * * \\
(14.87)\end{array}$ & $\begin{array}{l}-0.041 \\
\quad(-0.37)\end{array}$ \\
\hline Obs & 6,939 & 1,088 & 6,939 & 1,005 \\
\hline
\end{tabular}

${ }^{a} b_{1}$-Coefficients of $\hat{\varepsilon}^{2}=b_{0}+b_{1}$; Fairtrade Result of OLS and Quantile Regressions; Significance levels $1 \%(* * *), 2 \%(* *), 5 \%(*) .10 \%\left({ }^{+}\right)$

result, in turn, could indicate that consumers search more for less expensive Fairtrade wine outlets than they do for regular wine.

When running quantile regression on the same squared residuals, we find similar results. The Fairtrade effect on dispersion is invariably negative and increases in significance in higher price quantiles.

In column (3) of Table 3, we report the OLS and quantile results based on the IV regressions in Table 2, column (3). Now, the sign has turned. In OLS and quantile regressions, we find strong and statistically significant positive Fairtrade effects on the squared residuals, suggesting that Fairtrade wines exhibit substantially larger price dispersions than do regular wines. As shown in the quantile regression, this dispersion-boosting effect appears to grow in higher price quantiles.

For completeness, we also report the results of the analysis of squared residuals as obtained from the equations that contain the critical wine scores (i.e., columns (2) and (4) in Tables 2 and 3). The IV results change and now resemble the estimates based on OLS residuals. Again, due to the entirely different sample size and the loss of many producer and varietal dummy variables, the comparability of the results of column (1) and (2) in Table 2 as well as (3) and (4) in Table 3 is limited. In addition, our confidence in the IV results is limited due to their suspected bias. 


\section{B. Separate Equations}

Instead of instrumenting the Fairtrade treatment we now run equation (1) separately for Fairtrade and Non-Fairtrade wines and compare the Coefficients of Variation (CV). Table 4 shows the results for two variants, without and with critical scores. The coefficients of Age, Trend, Score are considerably different between Fairtrade and Non-Fairtrade wines, an effect that, in Table 2, was captured by interactions. Running separate equations also allows for different marginal effects of all other variables. Overall, we find significantly lower CV values for Fairtrade wines than for Non-Fairtrade wines. This is particularly true when we also include quality scores. However, including scores leaves us with a sample of only 42 Fairtrade wines.

Table 5 reports the $\mathrm{CV}$ values for separate quantile regressions of Fairtrade and Non-Fairtrade wines. Again, in all quantiles and both variants, i.e., with and without quality scores, Fairtrade wines display smaller CV values, indicating a smaller price dispersion.

\section{Summary}

This paper analyzes wine price dispersion in the United Kingdom, the world's largest market for Fairtrade wine. We analyze whether Fairtrade wines exhibit a higher degree of price dispersion than do non-Fairtrade wines. This result could be due to lower search activities, because Fairtrade contains some social attributes in addition to its tangible value. That is, consumers might be willing to tolerate aboveaverage prices due to the positive social connotation of Fairtrade.

Table 4

Determinants of Wine Prices

Separate OLS Equations for Fairtrade and Non-Fairtrade

Dependent Variable $\ln ($ Price)

\begin{tabular}{lcccc}
\hline & $\begin{array}{c}\text { Non-Fairtrade } \\
\text { wlo scores } \\
(1)\end{array}$ & $\begin{array}{c}\text { Non-Fairtrade } \\
\text { with scores } \\
(2)\end{array}$ & $\begin{array}{c}\text { Fairtrade } \\
\text { wlo scores } \\
(3)\end{array}$ & $\begin{array}{c}\text { Fairtrade } \\
\text { with scores } \\
(4)\end{array}$ \\
\hline Age & $0.031^{* * *}$ & 0.289 & $0.160^{* * *}$ & $0.163^{* *}$ \\
& $(8.46)$ & $(1.19)$ & $(3.26)$ & $(6.02)$ \\
Trend & $0.018^{* * *}$ & -0.223 & -0.055 & -0.027 \\
& $(3.15)$ & $(-0.92)$ & $(-1.14)$ & $(-0.39)$ \\
Quality Score & & $0.030^{* * *}$ & & 0.091 \\
& & $(3.79)$ & & $(1.25)$ \\
Obs & 6,470 & 1,046 & 469 & 42 \\
R2 & 0.389 & 0.554 & 0.626 & 0.795 \\
RMSE & 0.389 & 0.416 & 0.278 & 0.187 \\
Coefficient of Variation $(\mathrm{CV})$ & $15.85 \%$ & $15.79 \%$ & $12.06 \%$ & $7.39 \%$ \\
\hline
\end{tabular}

All equations include fixed effects for producer, grape variety, and vintage. RMSE root mean squared error. 


\section{Table 5}

Coefficients of Variation for Fairtrade Wine and Non-Fairtrade Wine Results of Separate OLS and Quantile Regressions

\begin{tabular}{lccccc}
\hline & \multicolumn{2}{c}{ Non-Fairtrade Wine } & & \multicolumn{2}{c}{ Fairtrade Wine } \\
& $\begin{array}{c}(1) \\
\text { without scores }\end{array}$ & $\begin{array}{c}(2) \\
\text { with scores }\end{array}$ & & $\begin{array}{c}\text { (3) } \\
\text { without scores }\end{array}$ & $\begin{array}{c}\text { (4) } \\
\text { with scores }\end{array}$ \\
\hline OLS & 0.389 & 0.416 & & 0.278 & 0.187 \\
Quantile Regressions & & & & \\
$\tau=0.10$ & 0.344 & $(-)$ & & 0.296 & $(-)$ \\
$\tau=0.25$ & 0.265 & 0.280 & & 0.188 & 0.118 \\
$\tau=0.50$ & 0.225 & 0.228 & & 0.225 & 0.101 \\
$\tau=0.75$ & 0.269 & 0.266 & & 0.201 & 0.122 \\
$\tau=0.90$ & 0.393 & 0.525 & & 0.331 & 0.183 \\
Obs & 6,470 & 1,046 & & 469 & 42 \\
\hline
\end{tabular}

Coefficients of Variance based on equation (1) run separately for Fairtrade and Non-Fairtrade wines; (-) no convergence.

We approach this issue by first running a hedonic regression to explain wine retail prices. We then take the unexplained part (i.e., the [squared] residuals) and regress it over a Fairtrade dummy variable. A positive Fairtrade effect on the squared residuals would indicate a higher price dispersion level for Fairtrade wines, and vice versa.

Our results are conflicting. Our results based on OLS suggest that Fairtrade wines' price dispersion is lower compared to that of regular wines, our results based on IV regression indicate the opposite. However, since we cannot reject the null hypothesis of a substantial bias in our IV regression, we suspect that our instruments are weak and have little trust in our 2SLS estimates.

In order to abolish the requirement for any instrumentation, we finally ran two separate hedonic equations, one for non-Fairtrade wines and one for Fairtrade wines. A comparison of the respective coefficients of variation $(\mathrm{CV})$ lends support to our original OLS results and suggests that Fairtrade wine prices are, in fact, less disperse.

We do not include dummy variables for retail outlets, because doing so would substantially restrict the remaining degrees of freedom in all regressions with various entailing complications. However, investigating the retail outlet structure seems to be a useful extension of this work. Not only may the number of Fairtrade and non-Fairtrade outlets be different; their locations may be as well. Thus, one may imagine a situation where wine stores that carry Fairtrade wines are regionally less dispersed than others, giving Fairtrade stores a lower degree of monopoly power. Likewise, wine retail outlets that carry Fairtrade wines may be located predominantly in low-income neighborhoods. This situation, in turn, could lead to less price dispersion and render our "consumer search" explanation doubtful. 


\section{References}

Andreoni, J. (1990). Impure altruism and donations to public goods: A theory of warm-glow giving. Economic Journal, 100(401), 464-477.

Becker, G. S. (1974). A theory of social interactions. Journal of Political Economy, 82(6), 1063-1093.

Dragusanu, R., Giovannucci, D., and Nunn, N. (2014). The economics of fair trade. Journal of Economic Perspectives, 28(3), 217-236.

Fairtrade Foundation. (2012). History. Available at http://www.fairtrade.org.uk/what_is_fairt rade/history.aspx (accessed on July 9, 2012).

Fairtrade Foundation UK. (2017). Wine farmers and workers. Available at http://www.fairtrade.org.uk/Farmers-and-Workers/Wine (accessed on November 12, 2017).

Fairtrade Label South Africa. (2012). Fairtrade wine products. Available at http://www.fairtr adelabel.org.za/product/wine.1.html (accessed on July 9, 2012).

FLO-CERT. (2012). Website. Available at http://www.flo-cert.net/flo-cert/28.html (accessed on July 9, 2012).

Granville, B., and Telford, S. (2013). Empirical evidence from South Africa. In Granville, B., and Dine, J. (eds.), The Processes and Practices of Fair Trade: Trust, Ethics, and Governance, 286-340. New York: Routledge.

Jaeger, D. A., and Storchmann, K. (2011). Wine retail price dispersion in the United States: Searching for expensive wines? American Economic Review, Papers and Proceedings, 101(3), $136-141$.

Olson, M. (1965). The Logic of Collective Action. Cambridge, Mass: Harvard University Press.

Pratt, J. W., Wise, D. A., and Zeckhauser, R. (1979). Price differences in almost competitive markets. Quarterly Journal of Economics, 93(2), 189-211.

Sorensen, A. T. (2000). Equilibrium price dispersion in retail markets for prescription drugs. Journal of Political Economy, 108(4), 833-850.

Wine Searcher. (2017). Wine scores. Available at https://www.wine-searcher.com/wine-scores. lml (accessed on November 10, 2017). 